\title{
VARIABILITY IN $\alpha$-TOCOPHEROL CONCENTRATION OF HUSKED AND NAKED OAT GENOTYPES
}

\author{
Linda Berga and Sanita Zute \\ State Stende Cereal Breeding Institute, "Dižzemes", Dižstende, Lībagu pag., Talsu nov., LV-3258, LATVIA \\ stende.selekcija@apollo.Iv
}

Communicated by Zinta Gaile

\begin{abstract}
Oat (Avena sativa L.) is recognised as a healthy food in the world. Oat contains significant amounts of fat-soluble vitamin $E$ ( $\alpha$-tocopherol), a substance with high antioxidant activity. The main tasks of this study were to characterise the variability of $\alpha$-tocopherol concentration of oat varieties and breeding lines bred in Latvia and foreign countries. Field trials were carried out at the State Stende Cereal Breeding Institute in 2007 and 2008. Sixty four oat genotypes (52 husked and 12 naked) were tested for $\alpha$-tocopherol using high-performance liquid-chromatography. The obtained results showed a wide range of $\alpha$-tocopherol concentration among both husked and naked oat genotypes. The $\alpha$-tocopherol concentration in husked oat varieties and lines varied from 3.2 to $8.4 \mathrm{mg} \mathrm{kg}^{-1}$ and for naked oat from 5.5 to $8.8 \mathrm{mg} \mathrm{kg}^{-1}$. The wide range of $\alpha$-tocopherol concentration in oat grown in Latvia showed that there is wide choice of material for breeding programmes and that further research should be carried out in future.
\end{abstract}

Key words: naked oat, husked oat, genotypes, $\alpha$-tocopherol, variability, breeding lines.

\section{INTRODUCTION}

Oat (Avena sativa L.) is a well known annual crop in temperate climates. Morphologically, oat can be classified as husked and naked; naked oat is nutritionally richer than the common husked oat. Naked oat has a thin non-lignified husk on the outside of the grain which falls off during harvesting. This results in higher energy grain that contains more protein and lipids and less fibre compared to conventional oat (Tiwari and Cummins, 2009). Furthermore, naked oat is associated with good agricultural features that could be beneficial for organic farming (Welch, 1995; Biel et al., 2009).

Much of the cholesterol-lowering capacity in oat is attributed to its high soluble fiber ( $\beta$-glucan) concentration. There are, however, other phytonutrients that likely contribute to the overall health benefits, like water-soluble B vitamins and fat-soluble vitamin $\mathrm{E}$ ( $\alpha$-tocopherol). The high level of $\alpha$-tocopherol found in oat is of note because of its antioxidant activity and link to prevention of cardiovascular disease, Alzheimer disease, glaucoma, and prostate cancer (Welch, 1995; Jackson et al., 2008). There are no reliable reports of the presence of vitamin $\mathrm{C}$, vitamin $\mathrm{B}_{12}$, or the fat-soluble vitamin A or D in oat.

Vitamin E activity is provided by the tocopherols and tocotrienols, which together create tocols. Tocols are fat soluble and form part of the total lipid. The vitamin activity of tocols is associated with their antioxidant function in vivo. Tocotrienols and tocopherols differ in their prenyl side chains; tocotrienols have an unsaturated geranylgeranyl side chain and tocopherols have a saturated phytyl side chain. Each class consists of four homologues, termed alpha, beta, gamma and delta, depending on the methylation pattern on the chromonal ring. The highest level of vitamin E activity is produced by $\alpha$-tocopherol (Fig. 1), following by $\beta$-tocopherol and $\alpha$-tocotrienol, which have $40 \%$ and $30 \%$ of the activity of $\alpha$-tocopherol, respectively on an equal weight basis (Welch, 1995; Zielinski et al., 2001; Jackson et al., 2008). Alpha-tocopherol is a major antioxidant component in crude oat lipids and is unaltered when the lipid is refined (Webster, 1986); $\beta$ - and $\gamma$-tocopherols have also been detected in crude oat lipids, but in minor amounts.

The effects of environment and genotype interactions on oat grain quality are poorly documented. Choice of genotypes, growing technologies and climate affect vitamin content in oat (Doehlert et al., 2001). Therefore, during the recent decade oat breeders have paid attention to genotypes with high<smiles>Cc1c(C)c2c(c(C)c1O)CCC(C)(C=CC=CC(C)C)O2</smiles>

Fig. 1. The chemical structure of $2 \mathrm{R}, 4^{\prime} \mathrm{R}, 8^{\prime} \mathrm{R}-\alpha$-tocopherol. 
quality traits persistent. Furthermore, it would be useful to include such genotypes as source material in breeding programmes.

The objective of this study was to determine the $\alpha$-tocopherol concentration in oat varieties and breedinglines grown in Latvia. The study included breeding material selected in oat breeding programme at the State Stende Cereals Breeding Institute.

\section{MATERIALS AND METHODS}

The field trials were carried out at the State Stende Cereals Breeding Institute in 2007 and 2008. The material consisted of 64 oat genotypes (int. al. 52 husked and 12 naked). Among the genotypes, 34 (int. al. 27 husked and 7 naked) varieties and breeding lines were from Latvia and the remaining 30 (int. al. 25 husked and 5 naked) were of foreign origin. The soil of the site was sod-podzolic. The main soil factors were: humus concentration $18 \mathrm{~g} \mathrm{~kg}^{-1}$ in 2007 and $26 \mathrm{~g} \mathrm{~kg}^{-1}$ in 2008, soil $\mathrm{pH} \mathrm{KCl}-6.2$ in 2007 and 6.1 in 2008, available phosphorus $\mathrm{P}_{2} \mathrm{O}_{5}-193 \mathrm{mg} \mathrm{kg}^{-1}$ in 2007 and 334 in 2008, and potassium $\mathrm{K}_{2} \mathrm{O}-143 \mathrm{mg} \mathrm{kg}^{-1}$ in 2007 and 164 in 2008. The pre-crop was winter wheat in both years. All agro-technical operations were carried out at optimal times according to the weather conditions during the vegetation period and depending on the plant development phases. Seeding rate was 500 seeds per $1 \mathrm{~m}^{2}$. Before cultivation of the soil a complex mineral fertiliser was applied: N-51, $\mathrm{P}_{2} \mathrm{O}_{5}-30, \mathrm{~K}_{2} \mathrm{O}-42 \mathrm{~kg} \mathrm{ha}^{-1}$ (2007), N-56, $\mathrm{P}_{2} \mathrm{O}_{5}-56, \mathrm{~K}_{2} \mathrm{O}-56 \mathrm{~kg} \mathrm{ha}^{-1}$ (2008). Variants were arranged in four replications with plot size $2 \mathrm{~m}^{2}$ in a randomised block design.

Meteorological conditions of both years were. rather inappropriate for oat growing. Mean daily temperature in 2007 in the vegetation period was higher than the next year and the long-term average, but in 2008 it was even lower than long-term average. Precipitation in May was higher in 2007 and provided good oat field germination, compared with May in 2008, when precipitation was twice lower than the long-term average. Both investigation years were characterised by abundant rainfall and mean values of several months exceeded the long-term observed monthly norm. Frequent heavy rainfall occurred in July and August causing lodging in both years and decreasing yield and grain quality of oat. Consequently, harvesting was delayed approximately by ten days in both years.

Mean samples from all replications $(0.5 \mathrm{~kg})$ were taken and milled for $\alpha$-tocopherol determination in the Laboratory of Food and Environmental Investigations of the Institute of Food Safety, Animal Health and Environment BIOR, using high-performance liquid-chromatography. The method is often used for detection of $\alpha$-tocopherol in diet samples. Absorption was measured at $292 \mathrm{~nm}$. Chromatography was carried out in a C18 column using methanol/water liquid $(98 / 2 \mathrm{v} / \mathrm{v})$. The concentration was determined as $\mathrm{mg} \mathrm{kg}^{-1}$ in dry matter. The obtained results were statistically processed using descriptive statistics in the MS Excel software package. Means were compared using a t-test to determine significant differences between years and between husked and naked oat types.

\section{RESULTS}

In 2007 , the concentration of $\alpha$-tocopherol varied from 5.6 to $8.8 \mathrm{mg} \mathrm{kg}^{-1}$ in husked oat grain, and from 3.2 to $8.4 \mathrm{mg}$ $\mathrm{kg}^{-1}$ in naked oat. The average $\alpha$-tocopherol concentration in both years for naked oat $\left(7.4 \mathrm{mg} \mathrm{kg}^{-1}-2007,6.9 \mathrm{mg}\right.$ $\mathrm{kg}^{-1}$ - 2008) was significantly $(P<0.05)$ higher than in husked oat $\left(5.9 \mathrm{mg} \mathrm{kg}^{-1}\right.$ - 2007, $6.2 \mathrm{mg} \mathrm{kg}^{-1}$ — 2008) (Table 1). Higher variation in $\alpha$-tocopherol concentration in both years was observed for husked oat (coefficient of variation 18 and $12 \%$ ).

Table 1

CONCENTRATION OF $\alpha$-TOCOPHEROL IN OAT GRAIN ( $\mathrm{mg} \mathrm{kg}^{-1}$ dry matter 2007-2008, State Stende Cereal Breeding Institute)

\begin{tabular}{l|cr|c|c}
\hline \multirow{2}{*}{ Indices } & \multicolumn{2}{c|}{ Naked oat, $\mathrm{n}=12$} & \multicolumn{2}{c}{ Husked oat, $\mathrm{n}=52$} \\
\cline { 2 - 5 } & 2007 & 2008 & 2007 & 2008 \\
\hline Mean & $7.4 \mathrm{a}^{* 1}$ & $6.9 \mathrm{~b}^{*}$ & $5.9 \mathrm{~b}$ & $6.2 \mathrm{a}$ \\
Min & 5.6 & 5.5 & 3.2 & 4.6 \\
Max & 8.8 & 7.9 & 8.4 & 7.7 \\
CV & $11 \%$ & $9 \%$ & $18 \%$ & $12 \%$
\end{tabular}

${ }^{1}$ Trait means followed by different letters are significant between the years at the level of $P<0.05$; * trait means that are significantly higher, comparing husked and naked oat types $(P<0.05)$.

In 2008, the $\alpha$-tocopherol concentration for husked oat genotypes varied from 4.6 to $7.7 \mathrm{mg} \mathrm{kg}^{-1}$, and for naked oat genotypes from 5.5 to $7.9 \mathrm{mg} \mathrm{kg}^{-1}$. A significant difference $(\mathrm{P}<0.05)$ in $\alpha$-tocopherol concentration was found between years for both types of oat.

The distribution trends in the frequency of $\alpha$-tocopherol concentration were continuous in the 52 husked oat genotypes (Fig. 2). The largest number of genotypes of husked oat had $\alpha$-tocopherol concentration in the classes 6.0-7.0 $\mathrm{mg} \mathrm{kg}^{-1}$ and 5.0-6.0 mg kg ${ }^{-1}$. For four genotypes of husked oat the $\alpha$-tocopherol concentration exceeded $7.0 \mathrm{mg} \mathrm{kg}^{-1}$, and of 12 naked oat genotypes five exceeded this value. Two naked oat genotypes had a $\alpha$-tocopherol concentration higher than $8.0 \mathrm{mg} \mathrm{kg}^{-1}$.

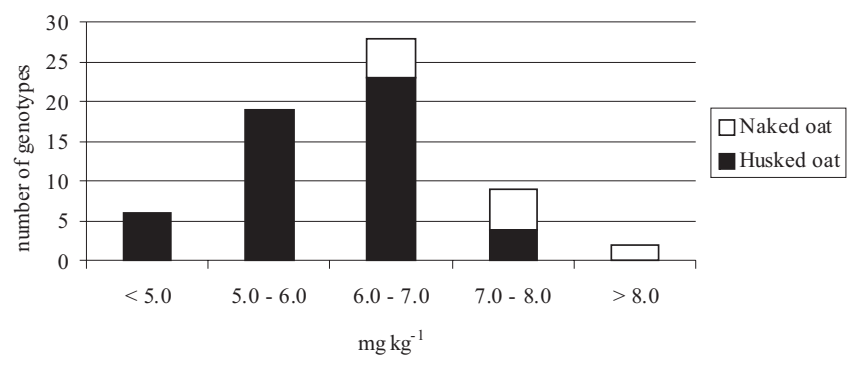

Fig. 2. Frequency distribution of $\alpha$-tocopherol concentration $\left(\mathrm{mg} \mathrm{kg}^{-1}\right)$ among oat genotypes, average of 2007-2008. 
FOREIGN HUSKED AND NAKED OAT GENOTYPES WITH HIGH $\alpha$-TOCOPHEROL CONCENTRATION ( $\mathrm{mg} \mathrm{kg}^{-1}, 2007-2008$, State Stende Cereal Breeding Institute)

\begin{tabular}{l|l|c|c|c|c}
\hline $\begin{array}{c}\text { Oat } \\
\text { genotypes }\end{array}$ & $\begin{array}{c}\text { Country of } \\
\text { origin }\end{array}$ & 2007 & 2008 & Mean & $\begin{array}{c}\text { Difference } \\
\text { between } \\
\text { years } \\
\text { (absolute } \\
\text { value) }\end{array}$ \\
\hline \multicolumn{5}{c}{ Husked oat } \\
'Aragon' & Germany & 8.4 & 6.8 & 7.6 & 1.6 \\
'Selma' & Sweden & 7.5 & 7.6 & 7.5 & 0.1 \\
'Margarett' & Sweden & 6.6 & 7.7 & 7.2 & 1.1 \\
'Hecht' & Germany & 7.3 & 6.7 & 7.0 & 0.6 \\
& & Naked oat & & & \\
'Adam' & Czech Republic & 8.8 & 7.9 & 8.4 & 0.9 \\
'Izak' & Czech Republic & 7.8 & 7.0 & 7.4 & 0.8 \\
'NosNacht' & Germany & 7.1 & 7.4 & 7.3 & 0.6 \\
'Beloruskij & Belarus & 7.3 & 6.7 & 7.0 & 0.3 \\
Golozernij' & & & & &
\end{tabular}

Four of 25 foreign origin husked oat genotypes ('Aragon', 'Selma', 'Margarett' and 'Hecht') had high $\alpha$-tocopherol concentration $-7.6,7.5,7.1$ and $7.0 \mathrm{mg} \mathrm{kg}^{-1}$, respectively (Table 2). A more stable $\alpha$-tocopherol concentration was found in the varieties 'Selma' and 'Hecht', as between years the concentration differed by 0.1 and $0.6 \mathrm{mg} \mathrm{kg}^{-1}$, respectively.

Four foreign naked oat varieties exceeded the concentration of $7.0 \mathrm{mg} \mathrm{kg}^{-1}$ : 'Adam', 'Izak', 'NosNacht', and 'Beloruskij Golozernij'. The variety 'Adam' had a very high $\alpha$-tocopherol concentration $-8.4 \mathrm{mg} \mathrm{kg}^{-1}$. For all these varieties the difference between years was lower than $1.0 \mathrm{mg} \mathrm{kg}^{-1}$.

Among the Latvian genotypes, the variety 'Arta' had the highest $\alpha$-tocopherol concentration $-7.5 \mathrm{mg} \mathrm{kg}^{-1}$, and there was no significant difference between years (Table 3). The lowest differences between years were for varieties 'Arta' and 'Stendes Darta' ( 0.0 and $0.8 \mathrm{mg} \mathrm{kg}^{-1}$, respectively).

Latvian breeding line 32190 (Bor 88601/Katri) had the highest $\alpha$-tocopherol concentration $-7.0 \mathrm{mg} \mathrm{kg}^{-1}$; while none of the other breeding lines exceeded the concentration of $7.0 \mathrm{mg} \mathrm{kg}^{-1}$. The difference between years for line 32190 was only $0.2 \mathrm{mg} \mathrm{kg}^{-1}$.

Among naked oat genotypes, the highest $\alpha$-tocopherol concentration - 8.1 mg kg-1 was found for line 30634 (NosNacht/Adam). For three oat lines 30616, 30617, and 30629 the average $\alpha$-tocopherol concentration was above $7.0 \mathrm{mg} \mathrm{kg}^{-1}$. The highest difference between years was observed for line $30629-1.4 \mathrm{mg} \mathrm{kg}^{-1}$.

\section{DISCUSSION}

In Latvia, oat has been mostly studied as raw material for the human diet. Parametres that have been studied include
CHARACTERISATION OF LATVIAN HUSKED AND NAKED OAT GENOTYPES (mg kg ${ }^{-1}, 2007-2008$, State Stende Cereal Breeding Institute)

\begin{tabular}{|c|c|c|c|c|}
\hline Oat genotypes & 2007 & 2008 & Mean & $\begin{array}{l}\text { Difference } \\
\text { between } \\
\text { years (abso- } \\
\text { lute value) }\end{array}$ \\
\hline \multicolumn{5}{|c|}{ Husked oat } \\
\hline 'Arta' & 7.5 & 7.5 & 7.5 & 0.0 \\
\hline 'Stmara' & 7.5 & 6.4 & 7.0 & 1.1 \\
\hline $\begin{array}{l}32190 \\
\text { BOR88601/Katri }\end{array}$ & 7.1 & 6.9 & 7.0 & 0.2 \\
\hline 'Stendes Līva' & 6.3 & 7.3 & 6.8 & 1.0 \\
\hline 'Laima' & 6.9 & 5.9 & 6.4 & 1.0 \\
\hline 'Stendes Darta' & 4.6 & 5.2 & 4.9 & 0.8 \\
\hline PCU-32 & 3.2 & 4.9 & 4.1 & 1.7 \\
\hline \multicolumn{5}{|c|}{ Naked oat } \\
\hline $\begin{array}{l}30634 \\
\text { 'NosNacht'/‘Adam' }\end{array}$ & 8.4 & 7.8 & 8.1 & 0.6 \\
\hline $\begin{array}{l}30616 \\
\text { 'NosNacht'/‘Adam' }\end{array}$ & 8.0 & 7.2 & 7.6 & 0.8 \\
\hline $\begin{array}{l}30617 \\
\text { ('Skakun'/STH-362)/ } \\
\text { Hja } 82371\end{array}$ & 7.7 & 7.3 & 7.5 & 0.4 \\
\hline $\begin{array}{l}30629 \\
\text { ('Skakun'/STH-362)/ } \\
\text { Hja } 82371\end{array}$ & 7.8 & 6.4 & 7.1 & 1.4 \\
\hline $\begin{array}{l}30636 \\
\text { 'NosNacht'/'Adam' }\end{array}$ & 6.8 & 6.4 & 6.6 & 0.2 \\
\hline $\begin{array}{l}\text { P4707 } \\
\text { ('Skakun'/STH-362)/ } \\
\text { GA961003 }\end{array}$ & 7.0 & 5.5 & 6.3 & 1.5 \\
\hline $\begin{array}{l}31353 \\
\text { ('Arta'/'Kirovec')/ } \\
\text { BOR88534 }\end{array}$ & 5.6 & 6.9 & 6.3 & 0.7 \\
\hline
\end{tabular}

yield per hectare, volume weight, husk content, and crude protein content. However, these parameters does not describe the nutritive and dietary value of oat, which is an important criterion describing the quality of food. Oat differs from other cereals by balanced essential amino acid structure in protein, oil rich with unsaturated fatty acids, easily available starch and a comparatively high amount of $\beta$-glucan, and vitamins E and B5 (Jackson et al., 2008). Plant breeders should pay attention to biochemical indicators of cereals when developing new oat varieties for food production. In the Latvian oat breeding programme, the highest crude protein and crude lipid content are selection criteria in evaluation of the breeding material.

Oat genotypes bred in Latvia did not show and marked difference when compared with material of foreign origin. The difference between husked and naked oat genotypes can be explained by the differences in sample structure; husked oat samples include also hulls, which increases the amount of material in the sample without $\alpha$-tocopherol.

Both years of the field trials were inappropriate for oat growing. Meteorological conditions decreased gain yield, 
but the obtained $\alpha$-tocopherol results were similar to results described in the literature. In Australia using a similar analytical method the range of $\alpha$-tocopherol concentration was 7.0 to $14.9 \mathrm{mg} \mathrm{kg}^{-1}$ for husked oats (Ryan et al., 2007) while in Poland and Great Britain the concentration of $\alpha$-tocopherol in this type of oat was from $8.5-8.9 \mathrm{mg} \mathrm{kg}^{-1}$ (Zielinski et al., 2001; White et al., 2006). This suggests that in warmer climates, as in Australia, the $\alpha$-tocopherol concentration is higher than in countries with a cooler climate - Poland, Great Britain and Latvia. Also the genetic material from different countries differs much in chemical structure.

The obtained results showed a wide range of $\alpha$-tocopherol concentration among both husked and naked oat genotypes. A larger difference in $\alpha$-tocopherol concentration between years indicated the varieties and breeding lines unsuitable for our growing conditions. Wide variation in $\alpha$-tocopherol concentration allows to select varieties or breeding lines with higher $\alpha$-tocopherol concentration, which could be used in breeding programmes. Our results showed that oat variety 'Adam' from the Czech Republic could be very good material in hybridisation as a parent. Breeding lines 30634 and 30616, which have been developed from the variety 'Adam' also had high $\alpha$-tocopherol concentration.

There is a deficiency of research on the effects of growing or meteorological conditions on $\alpha$-tocopherol concentration. Two years of results are insufficient to determine the relationship between growing conditions and $\alpha$-tocopherol concentration. There were varieties and breeding lines with higher $\alpha$-tocopherol concentration in the first year and some gave better results in the second year, indicating a genotype-year interaction on trait variability. Reliable results could be obtained by repeating the field trials for more than two years. Also, laboratorial analyses need to be carried out in replications, but this has not been possible due to costs of chemical reagents.

We observed a wide range of $\alpha$-tocopherol concentration in oat genotypes grown in Latvia, and suggested candidates that might be used in breeding programmes. Further research is needed and will be carried out in the future.

\section{ACKNOWLEDGEMENTS}

This work was supported by the Latvian State Research Programme in Agrobiotechnology.

\section{REFERENCES}

Biel, W., Bobko, K., Maciorowski, R. (2009). Chemical composition and nutritive value of husked and naked oats grain. J. Cereal Sci., 49, 413-418.

Doehlert, D.C, McMullen, M.S., Hammond, J.J. (2001). Genotypic and environmental effects on grain yield and quality of oat grown in North Dakota. Crop Sci., 41, 1066-1072.

Jackson, E.W., Wise, M., Bonman, J.M., Obert, D.E., Hu, G., Peterson, D.M. (2008). QTLs Affecting $\alpha$-tocotrienol, $\alpha$-tocopherol and total tocopherol concentrations detected in the Ogle/TAM O-301 Oat Mapping Population. Crop Sci., 48, 2141-2152.

Ryan, D., Kendall, M., Robards, K. (2007). Bioactivity of oats as it relates to cardiovascular disease. Nutr. Res. Rev., 20, 147-162.

Tiwari, U., Cummins, E. (2009). Simulation of the factors affecting $\beta$-glucan levels during the cultivation of oats. J. Cereal Sci., 50, 175-183.

Webster, F.H. (1986). Oats: Chemistry and Technology. USA, American Association of Cereal Chemists. 220 pp.

Welch, R.W. (1995). The Oat Crop: Production and Utilization. London, Chapman \& Hall. 516 pp.

White, D.A., Fisk, I.D., Gray, D.A. (2006). Characterisation of oat (Avena sativa $\mathrm{L}$.) oil bodies and intrinsically associated E-vitamins. J. Cereal Sci., 43, 244-249.

Zielinski, H., Ciska, E., Kozlowska, H. (2001). The cereal grains: Focus on vitamin E. Czech. J. Food Sci. 19, 182-188.

\section{ALFA-TOKOFEROLA DAUDZUMA IZMAIN̦AS KAILGRAUDU UN PLĒKŠṆAINO AUZU GENOTIPOS}

Auzas (Avena sativa L.) visā pasaulē ir pazīstamas kā veselīga uztura sastāvdaḷa. Tās satur nozīmīgus daudzumus taukos škīstošā E vitamīna ( $\alpha$-tokoferola) — biokīmiskas vielas ar augstu antioksidanta aktivitāti. Šì pētījuma mērkis ir aprakstīt $\alpha$-tokoferola daudzuma izmaiņas kailgraudu un plēkšņainajās auzās, izmantojot Latvijas un citu valstu šķirnes un selekcijas līnijas. Lauku izmēǵinājumi notika 2007. un 2008. gadā Valsts Stendes graudaugu selekcijas institūtā. Izmantojot augstas ižširtspējas škiidruma hromatogrāfijas metodi, tika analizētas sešdesmit četras Latvijā un citās valstīs radītās auzu šķirnes un līnijas (52 plēkšṇainas un 12 kailgraudu), lai noteiktu $\alpha$-tokoferola daudzumu. Alfa-tokoferola analǐžu rezultāti ḷauj izvēlēties šķirnes un līnijas ar augstu tā sastāvu, lai tās izmantotu selekcijas programmā. Tomēr divu gadu rezultāti nav pietiekoši uzticami, lai varētu aprakstīit $\alpha$-tokoferola atkarību no audzēšanas apstākḷiem, tādēl pētījumi tiks turpināti. 